\title{
VERIFICATION OF THE PRESENCE OF CAPSULE GENE SEQUENCES IN NASOPHARYNGEAL ISOLATES OF NONTYPEABLE HAEMOPHILUS INFLUENZAE FROM HEALTHY CHILDREN AT A BRAZILIAN DAY CARE CENTER
}

\author{
Maria Emilia Bonifácio da Silva ${ }^{1}$; José Moacir Marin²* \\ ${ }^{1}$ Departamento de Microbiologia, Universidade Estadual Paulista, Jaboticabal, SP, Brasil; ${ }^{2}$ Departamento de Morfologia, \\ Estomatologia e Fisiologia, Faculdade de Odontologia, Universidade de São Paulo, Ribeirão Preto, SP, Brasil \\ Submitted: March 12, 2001; Returned to authors: May 07, 2001; Approved: September 03, 2001
}

\section{SHORT COMMUNICATION}

\begin{abstract}
Fifty-eight nasopharyngeal isolates of Haemophilus influenzae were collected from healthy children at a day care center, and nontypeable isolates were examined by Southern blot for the presence of capsule gene sequences. Seven isolates (12\%) demonstrated homology with capsule-specific sequences. One isolate was characterized as an $H$. influenzae type b capsule-deficient strain.
\end{abstract}

Key words: Haemophilus influenzae, cap gene, day-care center

Haemophilus influenzae is a Gram-negative bacterium that commonly inhabits the human upper respiratory tract. Isolates of $\mathrm{H}$. influenzae $(\mathrm{Hi})$ are subdivided into encapsulated and nonencapsulated forms (10). Encapsulated strains express one of six structurally and antigenically distinct capsular polysaccharides, designated serotypes a to $f(10)$. All encapsulated strains of $\mathrm{Hi}$ have genes necessary for encapsulation (cap genes) (8). Nonencapsulated strains are defined on the basis of their failure to agglutinate with typing antisera against the known $\mathrm{Hi}$ capsular structures and are referred to as nontypeable (10). $\mathrm{Hi}$ causes bacterial meningitis and other life-threatening infections in young children and represents a significant health hazard all over the world. Type $b$ strains are responsible for over $95 \%$ of invasive infections caused by $\mathrm{Hi}$ (15). Musser et al. (7) proposed that the ancestor of $H i$ was encapsulated and that serologically nontypeable clones arose by convergent evolutionary loss of the ability to synthesize or extracellularly express a polysaccharide capsule.

St Geme et al. (14) reported that 43 (35\%) of 123 pharyngeal isolates of nontypeable $\mathrm{Hi}$ collected from healthy 3 -year-old
Finnish children contain capsule sequences. With the exception of limited data available from studies of $H i$ type $b$ (Hib) strains recovered in restricted settings in Brazil and Chile (6), little is known about the nature of strains from South America. In this study we examined nasopharyngeal isolates of serologically nontypeable and typeable $\mathrm{Hi}$ and studied these for their ability to hybridize with the cap gene in the plasmid pUO38.

In July and December a single nasopharyngeal swab was obtained from children attending Carochinha, a day care center on the Ribeirão Preto Campus, São Paulo University. At the center the children were grouped by age in modules from 6 to 37 months. $H i$ colonization was investigated in 38 children. This subpopulation comprised $61 \%$ of the children enrolled at the center. The Ethics Committee in charge of health control at the day care center approved the research protocol. Signed informed consent was obtained from a parent or guardian of each child. After collection, all specimens were placed in modified Stuart transport medium (Difco, Detroit-USA), transported to the laboratory and processed immediately.

\footnotetext{
* Corresponding author. Mailing address: Departamento de Morfologia, Estomatologia e Fisiologia, Faculdade de Odontologia, Universidade de São Paulo, Av. do Café, S/N, Campus USP, 14040-904, Ribeirão Preto, SP, Brasil. Tel.: (+5516) 602-4035, Fax: (+5516) 633-0999. E-mail: jmmarin@rge.fmrp.usp.br
} 
Swabs were inoculated onto selective medium consisting of: $10 \%$ horse blood-chocolate brain heart infusion agar plate (Difco) supplemented with $300 \mathrm{mg} / \mathrm{L}$ bacitracin. The isolates were identified by Gram staining, recognition of typical morphology on chocolate agar plates, NAD requirement for growth by the satellite phenomenon on ordinary blood agar, and by the inability to convert $\gamma$ aminolevulinic acid (Sigma, St Louis-USA) to porphyrins. Fermentation of glucose, sucrose, lactose, xylose and mannose in phenol red broth base (Difco) was performed for species identification (3). Capsular serotyping was done by slide agglutination with antisera to $H i$ types a-f (Difco). Biotypes were assigned to isolates on the basis of the ability to produce indole, urease and ornithine decarboxylase (3). Isolates were long term stored at ${ }^{-} 70^{\circ} \mathrm{C}$ in supplemented brain heart infusion broth with $50 \%$ glycerol.

High-molecular-weight chromosomal DNA was extracted from $\mathrm{Hi}$ isolates as described by Pitcher et al. (9) and the NCTC 7279 strain was used as Hib wild-type control. Genomic DNA (3ug) was digested to completion with EcoRI (Bethesda Research Laboratories, Gaithersburg-USA) according to manufacturer instructions, eletrophoresed on $0.7 \%$ agaroseTris acetate gels, and transferred to nylon membranes. Nick translation and Southern hybridization were performed by standard techniques (11) or as described by Smith-Vaughan et al. (12).

Escherichia coli $\mathrm{DH} 5 \alpha$ was used for plasmid propagation and the DNA plasmid was isolated by the alkaline method (11). The pUO38 plasmid contains a complete set of the cap genes $(18.0 \mathrm{~kb})$ from a wild type strain of $H i b$.

The nasopharyngeal cultures were positive for $\mathrm{Hi}$ in 28 children (75.6\%) in July and for 30 children $(78.9 \%)$ in December (results not shown). The 58 isolates were biotyped and serotyped (results not shown). All of them were examined by Southern analysis after digestion with Eco RI, by probing with pUO38. Using high-stringency conditions, 13 isolates demonstrated specific bands of hybridization. Six typeable isolates showed the type $b$ pattern of hybridization (results not shown) and seven nontypeable isolates (12\%) also showed specific hybridization. Among the seven nontypeable $\mathrm{Hi}$ isolates with evidence of capsule sequences there were 6 different hybridization patterns. Three of them showed a single band while the other four showed multiple bands (Table 1). Although more than $98 \%$ of natural isolates of Hib carry a duplication of 18 kilobases $(\mathrm{kb})$ of DNA at the cap locus, the loss of a copy of cap gene is a common event as already described $(4,14)$. A hypothesis discuted by Musser et al. $(7)$ is that the $H i$ ancestor is encapsulated and nonencapsulated strains evolved by point mutations or deletions. If this hypothetical scenario is correct one prediction would be that some nonencapsulated strains might contain vestigial capsule genes. St Geme et al. (14) described the first systematic examination of nontypeable $H i$ for evidence of capsule genes and found $35 \%$ of the isolates with this caractheristic, while our result indicated only $12 \%$. This difference could be explained by the fact that we examined a small number of isolates.

Fig. 1 shows two Southern hybridization patterns of nontypeable $H i$ isolates, which were identical to those described by St Geme et al. (14). Isolate 22 was identical to St Geme 436, without the $9.0 \mathrm{~kb}$ fragment. Absence of this fragment is typical of type b strains that have lost one copy of a repeated segment comprising the cap b locus and become capsule-deficient.

Table 1. Southern hybridization patterns of serologically nontypeable Haemophilus influenzae isolates that hybridize with pUO38.

\begin{tabular}{cc}
\hline Isolates & Hybridizing Eco RI fragments $(\mathrm{Kb})$ \\
\hline 5,10 & 17 \\
8 & $17,4.4$ \\
14 & 4.4 \\
22 & $10.7,5.6,4.4,2.7,2.1$ \\
26 & $5.6,5.4$ \\
31 & $4.4,0.9$ \\
\hline
\end{tabular}

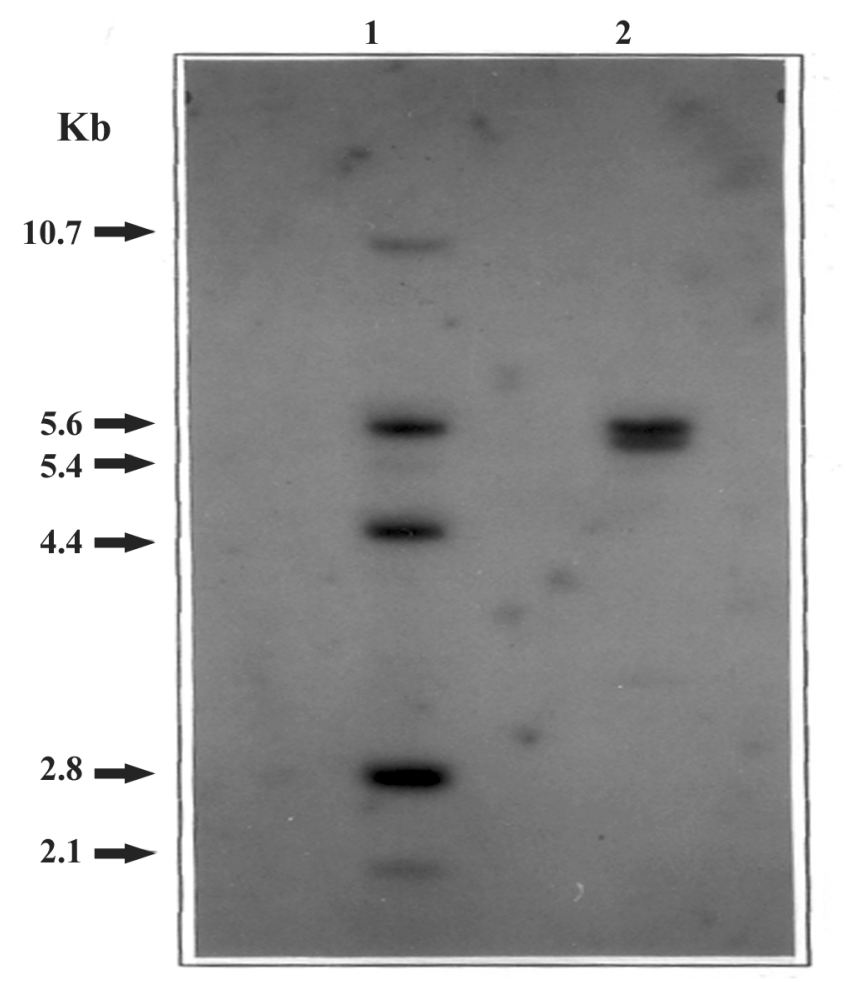

Figure 1. Southern hybridization results with representative isolates demonstrating hybridization with pUO38. Chromosomal DNA was digested with Eco RI before Southern analysis. Strains by lane: 1 . isolate 22 ; lane 2 . isolate 26 . The sizes of fragments are indicated on the left in Kilobases. 
Isolate 26 was identical to the most common St Geme nontypeable isolates with vestigial cap sequences. The capsule loss may be a device for evading the host-immune response, as well as for allowing the organism to adhere better to epithelial cells $(2,13)$.

Noncapsulated Hib mutants have been reported in different studies $(1,5,14)$ and the possibility that nonencapsulated Hib variants can revert to the capsular form and cause new outbreaks of invasive Hib disease has been carefully considered (12).

In conclusion our data support the hypothesis that nontypeable strains of $\mathrm{Hi}$ could arise from an encapsulate ancestor, and also reinforce the necessity of monitoring the presence of $H i$ at day care centers.

\section{ACKNOWLEDGEMENTS}

We thank Mrs. Ana Maria Mello, Director of the day care center, for allowing the study to take place and for obtaining informed consent from parents of enrolled children, Mrs. Suzel Nogueira Neme and Mr. Paulo da Silva from Instituto Adolfo Lutz for laboratory assistance, and E.R. Moxon from John Radcliffe Hospital, Oxford-UK for providing the plasmid pUO38.

\section{RESUMO}

\section{Verificação da presença de seqüências do gene da cápsula em cepas não tipáveis de Haemophilus influenzae isoladas da nasofaringe de crianças saudáveis em uma creche brasileira}

Cinqüenta e oito cepas de Haemophilus influenzae foram isoladas da nasofaringe de crianças saudáveis que freqüentam uma creche, e através da técnica de Southern blot foi pesquisada nas cepas acapsuladas a presença de seqüências do gene capsular. Sete cepas $(12 \%)$ caracterizadas sorologicamente como acapsuladas mostraram homologia com seqüências específicas da cápsula. Uma cepa foi caracterizada com uma linhagem $H$. influenzae tipo b cápsula deficiente.

Palavras-chave: Haemophilus influenzae, gene cap, creche

\section{REFERENCES}

1. Falla, T.J.; Crook, D.W.M.; Anderson, E.C.; Ward, J.L.; Santosham, M.; Eskola, J.; Moxon, E.R. Characterization of capsular genes in Haemophilus influenzae isolates from $H$. influenzae type b vaccine recipients. J. Infect. Dis., 17:1075-1076, 1995.

2. Hoiseth, S.K.; Connelly, C.J.; Moxon, E.R. Genetics of spontaneous, high-frequency loss of b capsule expression in Haemophilus influenzae. Infect. Immun., 49:389-395, 1985.

3. Kilian, M.; Biberstein, E.L. Genus Haemophilus. In: Krieg, J.S.; Holt, J.G. (eds). Bergey's Manual of Systematic Bacteriology. Williams \& Wilkins, Baltimore, 1984, pp.558-569.

4. Kroll, J.S.; Hopkins, I.; Moxon, E.R. Capsule loss in Haemophilus influenzae type $\mathrm{b}$ occurs by recombination-mediated disruption of a gene essential for polysaccharide export. Cell, 53:347-356, 1988.

5. Muhlemann, K.; Baltz, M.; Aebi, S.; Schopfer, K. Molecular characteristics of Haemophilus influenzae causing invasive disease during the period of vaccination in Switzerland: analysis of strains isolated between 1986 and 1993. J. Clin. Microbiol., 34:560-563, 1996.

6. Musser, J.M.; Kapur, V. Molecular population genetics of Haemophilus influenzae. In: Ellis, R.W.; Granoff, D.M. (eds). Development and clinical uses of Haemophilus type b vaccine, Marcel Dekker, New York, 1994.

7. Musser, J.M.; Barenkamp, S.J.; Granoff, D.M.; Selander, R.K. Genetic relationships of serologically nontypable and serotype $b$ strains of Haemophilus influenzae. Infect. Immun., 52:183-191, 1986.

8. Musser, J.M.; Kroll, J.S.; Moxon, E.R.; Selander, R.K. Clonal population structure of encapsulated Haemophilus influenzae. Infect. Immun., 56:1837-1845, 1988.

9. Pitcher, D.G.; Saunders, N.A.; Owen, R.J. Rapid extraction of bacterial genomic DNA with guanidin thiocyanate. Lett. Appl. Microbiol., 8:151-156, 1989

10. Pitman, M. Variation and type specificity in the bacterial species Haemophilus influenzae. J. Exp.l Med., 53:471-495, 1931.

11. Sambrook, J.; Fritsch, E.F.; Maniatis, T. Molecular cloning: a laboratory manual, 2nd ed. Cold Spring Harbor, NY: Cold Spring Harbor Laboratory, 1989.

12. Smith-Vaughan, H.C.; Sriprakash, K.S.; Leach, A.J.; Mathews, J.D.; Kemp, D.J. Low genetic diversity of Haemophilus influenzae type b compared to Noncapsulated $H$. influenzae in a population in which $H$. influenzae is highly endemic. Infect. Immun., 66:3403-3409, 1998.

13. St Geme III, J.W.; Falkow, S. Loss of capsule expression by Haemophilus influenzae type b results in enhanced adherence to and invasion of human cells. Infect. Immun., 59:1325-1333, 1991.

14. St Geme III, J.W.; Takala, A.; Esko, E.; Falkow, S. Evidence for capsule gene sequences among pharyngeal isolates of nontypeable Haemophilus influenzae. J. Infect. Dis., 169: 337-342, 1994.

15. Turk, D.C. Clinical importance of Haemophilus influenzae. In: Haemophilus influenzae epidemiology, immunology, and prevention of disease. Elsevier/North-Holland Publishing, New York, 1982, p.3-9. 